\title{
Art and Research: A Portrait of a Humanities Faculty as an Inclusive Work- space
}

Christa-Maria Lerm Hayes

Krisis 40 (1): 180-202.

\begin{abstract}
At a time when monuments are falling and learning processes accelerating, it seems apposite to pay attention also to artworks commissioned by established institutions in order to give form to good intentions. This essay focuses on a commissioned portrait of female professors, on art (history) education, Dutch art policy and the former colonial (VOC) site that the University of Amsterdam occupies, in order to aide this institution's desired process to become more inclusive. It proposes Art(istic) Research as a realm that can contribute a thoughtful positioning of research and universities in visual and public domains: a necessary ally.

Since the essay was written in Summer 2019 (with additions), much has happened: the Faculty in question has been found to be the locus of ongoing sexual harassment. The student victims did not feel that the (internal) complaints procedures were safeguarding them. They went to the media. A first investigation found no systemic deficiencies. Since George Floyd's death, we know better what "systemic" means. The university's Board has admitted systemic failures.

This essay is meant to show that art (history) and philosophy can jointly analyze organizations as a basis for necessary conversations, followed by action . During Covid lock-down, it became deceptively obvious how unimportant art is. An essay such as this, can hopefully show how art can indicate institutional culture: e.g. in relation to how embedded the principle to consult specialists is, even if this seems to be unimportant. And that is a matter of life and death.
\end{abstract}

\section{Keywords}

Universities and art commissions, Artistic research, Universities and gender politics, Intersectionality, UvA history and VOC

\section{DOI}

$\underline{10.21827 / \text { krisis.40.1.37009 }}$

\section{Licence}

Licensed under a Creative Commons Attribution-NonCommercial 3.0 License (CC BY-NC 3.0). 


\section{Art and Research: A Portrait of a Humanities Faculty as an Inclusive Work- space}

Christa-Maria Lerm Hayes

At the University of Amsterdam (UvA) and in the Dutch academic system at large, we lag behind many other countries in the proportion of women among professors. There are still fewer than $1 / 4$ (Dutch Network of Women Professors 2019). The UvA, especially Faculty of the Humanities, has made considerable progress, so that further action is not planned. The Faculty was also (until May 2020) ${ }^{1}$ in the fortunate position not to have had to deal with public outrage like in the Law Faculty, where a long cover-up of blatantly sexist behaviour has come to light (Logtenberg 2019). The Faculty is also, of course, part of a system that is far from equal, where a considerable pay gap and alarming levels of aggressive behaviour exist, and where, in the department of Art and Cultural Studies e.g., 66 out of 69 staff members voted for a more democratic organization. ${ }^{2}$

To contribute to the positive developments the Faculty of Humanities wishes to engender, the Dean, Dutch Linguist Fred Weermann, makes training in "social safety" and performance reviews available, invests in coaching, and promotes "verbindende leiderschap": a connecting rather than dividing style of leadership. The University also took steps to make excellent female professors more visible: in the university library, an infographic on famous female academics throughout the University's history was created. Weermann's focus particularly notices that the artworks which visualize the policies of the institution are portrait paintings of professors from the University's history, and that they are almost exclusively of male colleagues. Aside from depicting previous representatives of the institution, they also demonstrate how one once considered, and should regard, professors as these official portraits are often modelled on those of Heads of State, both establishing and conveying status. The portraits are located in the meeting rooms of the Bushuis or Oostindisch Huis, where the Dean also has his office. (There is one portrait of a female professor, but it is by far the smallest, most informal portrait, differing from the others by the sitter being shown at closer range, not wearing a toga or suit, or having a book or other standard academic insignia with her. From the image, it is even unclear whether she was a professor or not.) Weermann set about changing the predominantly male optics in terms of the image that the Faculty projects and commissioned a group 
portrait of five female professors from his Faculty: Mieke Bal, Professor in Literary Theory; Anne van Grevenstein, Professor of Conservation and Restoration; Aafke Hulk, Professor of French Linguistics and Dean of the Faculty of Humanities between 2003 and 2008; José van Dijck, Professor of Comparative Media Studies (until 2016) and Dean of the Faculty of Humanities between 2008 and 2011; and Marita Mathijsen, Professor of Modern Dutch Literature. ${ }^{3}$ Most are now retired or have left leading positions in the Dutch academic landscape.

The oil painting was unveiled in May 2019 and accompanied by a "FredVlog", featuring a visit to the studio of the artist, Rogier Willems, by the Dean and Mieke Bal. The work has received a moderate amount of criticism: for some, it was deemed unrepresentative of the sitters' status and resembled more of a "theekransje" (de Vries 2019), whereupon Mieke Bal rightly answered that today it seems to her inappropriate to appear in an "exhibitionist" manner, and that, for her, a sign of professorial excellence is to stress teamwork, i.e. to be in a group - and by extension among the students (Bal 2019). Unease remains in the university community, where there is some talk of systemic problems and of certain isolated incidences (ReThink UvA). ${ }^{4}$ This article sets out to explore this question through an interpretation of this work. The approach sees itself in a Warburgian tradition, where gestures in (or relating to) artworks elucidate the position (or safety) in society of those not in a hegemonic position, such as women, Jews, artists - in short: of the "other". I take it to be a strength here to start from a close analysis of a work and in so doing feed the theoretical and philosophical debates that are taking place in this journal's pages (e.g. Krisis 2015 (2)). It seeks to provide a new perspective for understanding what artworks do as active objects that focus relations and behaviours in their location; in this context in relation to students, their education, their future, and their "disciplining".

As the institution's Professor of Modern and Contemporary Art History, I gave this work to my first-year art history students as an exam question, asking what iconographic knowledge can convey to the viewer, and which of any other elements of the work should one take into account for contributing to an interpretation. They all made much of the compositional communalities with Rembrandt van Rijn's group portrait of six (not five) male sitters, the Staalmeesters. They also said that the colouring was very different: bright, instead of sombre, that the facial expressions were also clearly differing between the glum men and the happy women. 
The painting's more "modern" style and execution did not find universal approval. The work was more often than not considered unsuccessful artistically, but still universally seen as a well-meant and valuable, indeed, a feminist project that did what it was meant to do: make female academics more visible by showing them in an accessible, a (semi-)public space: the foyer of the so-called VOC-room at the UvA's Oostindisch Huis, Kloveniersburgwal, Amsterdam.

The exam question was intended to elicit and test a transfer to this local case study of lessons learned in a lecture, where I presented to students, among other things, Victor Margolin's response to the Dr. Martin Luther King Junior Memorial in Washington DC, which Barack Obama had unveiled in 2013 as President of the USA. Margolin argued that:

Lei Yixin's [the sculptor's] experience as a creator of Chairman Mao statues [...] contradicts the narrative of Dr. King's life. [...] Sculpture based on the tenets of Socialist Realism was adopted as well by authoritarian leaders around the world. [...] The point of being 'with' the people rather than 'above' them was missed, [...] The choice of a black artist would have [had ...] significance in that a major issue of black history is the earlier exclusion of black workers from good jobs as well as the exclusion of black artists from the art world. [...]

What makes the [...] Memorial most problematic in the end is the inability of the Martin Luther King, Jr. National Memorial Project Foundation to understand the parameters within which its meaning is and will continue to be determined. [...] the totality of meaning depends on a relation between the work's appearance and the conditions of its production - [...] all the $[\ldots]$ factors that, in this case, contradict the spirit of Martin Luther King Jr.'s life and what he fought for (Margolin 2012, 400-408).

While my students were enthusiastic in class and identified, for example, the unsuitability of white stone for King's monument, I was apparently not very successful in enabling the envisaged transfer to a case study close to home on the basis of my one session. The group had just received a long list of lectures exclusively on iconography (mostly Christian). The most obvious oversight of my students in the exam was that they did not notice that what is colloquially called the "Staalmeesteressen" is the work of an artist, who could be described as belonging to a majority (Dutch, white and male). The Dean, (who also fits that - of course, deficient - 
description) and the artist both thought they could speak for, and visually represent, formidable women, according to his (or both their) own ideas - and apparently without a reflective layer which shows recognizable grappling with this problem. This is what Hélène Cixous found, for example, when she was able to consider elements of James Joyce's writings as an "écriture féminine" (Cixous 1972).

Indecipherable papers are strewn over the table at which the academics sit. Paper is not necessarily what binds these colleagues in their research: yes, student work is often (still) on paper, but marking essays is not what got these researchers where they are. Mieke Bal could have had a video camera in front of her, José van Dijk as Professor of Media maybe a smartphone with the logo of the The Royal Netherlands Academy of Arts and Sciences (KNAW), which she directed? The work of the women is extremely diverse; too diverse and individual in fact to think of them as collaborating on one research project. Is it purely their common gender identity that brings them together here? Maybe not: the one paper document that is most likely to bring these five women together in this clearly artificial situation could be the draft of a Faculty document, maybe a policy plan, which they would have received from none other than the Dean of the Faculty, the commissioner of the painting. This would render the sitters in a servile position.

A professorial gown hangs on a hook to one side, ready to be of service when these academics do want or need to show their status - rather than their achievements - within a university setting. Like other institutions, the UvA is proudly presenting cortèges of gown-clad groups of professors in the media, where the focus is on the diversity of those pictured: women, being less numerous, thus feel the need to invest more time than men, in order to be seen more often - for the benefit of the institution. In the painting, we thus see a group of women whose individual achievement is stripped, or rather not elicited from them in the first place, in favour of constructing the "feminist" project so easily read by my students - one for which the UvA, the Faculty, clearly wishes to take credit. There will be more instances where we find that the portrait is maybe more about the Faculty and the commissioner, rather than the sitters.

Apart from the papers and the gown, the two further iconographical elements are the mirror above the group and the women's clothing. The mirror shows the table and the edges of a head and the papers. Does it speak of the academics' achievements? It is more likely that the artist, 
on receiving his brief, could not help but associate the task of painting women with a mirror: it stands for beauty and, therefore, for women - doesn't it? The work invites a crude iconographic reading: for the male artist, the women, by their gender, call for the mirror to be present, but they are academics, so they are turning away from it, i.e. from the traditional traits and roles of women. Rembrandt's Staalmeesters does not feature a mirror, which could possibly have "excused" its inclusion.

Of all the sitters, maybe Mieke Bal has made the point most clearly in her always impeccably chosen dress and often rather striking jewellery: while being one of far too few women in her position, she wished to drive home to her male colleagues the fact that being a serious academic neither neuters a woman, nor reduces her to her gender. Both are, unfortunately, the case in this work. On the other hand, Marita Mathijsen related at the university's unveiling ceremony that the artist asked her to wear a green dress (presumably for the benefit of the colour composition), something she said she does not usually do. It is clear whose vision had to be painted: not that of the academics. Maybe the Staalmeesters also served as a compositional model, because they are the syndics of the Drapers' Guild: not academics but people whose lives centrally involves clothing. Is this for the male artist another commonality revealed among the sitters through their gender?

Of course, the mirror can mean more things than (a retrograde conception of female) beauty: it is both a symbol of vanitas and a tool. The artist can use it to show off his (traditionally his) trade: a proficiency at perspectival drawing, linked to the research elements of his craft and, therefore, access to truth. The spatial awkwardness of this painting excludes such a reading. Maybe the mirror enables a person's subjectivity, a critical reflection of their personality in the world? Indeed, but it does so very differently for women and men: Luce Irigaray credibly outlines that the mirror is to women something that emphatically does not serve her subjectivity. Instead, she is expected to use it to check her reflection's compliance with governing codes and standards of beauty. Thus the mirror is not there to meet her gaze equally, but it stands for and exercises the male gaze, towering over the women: the artist and the commissioning body, the still male-gendered institution. She is the (m)other, which enables male subjectivity to constitute itself (Robinson 2006, 65-66).

My students noticed that the papers on the Staalmeesters' table were not possible to be 
scrutinised, due to the painter's low perspective, which obscures the table top. The UvA academics do not focus on guild secrets, they publish and their papers are openly accessible, which is appropriate. It may, however, also spell out a male privilege to be able to withhold - yet another gender stereotype: that women are so communally-minded and share. The sitters' wish was (according to Bal) to be depicted humbly, among the students and colleagues envisaged as viewers: this, indeed, makes the painting more successful than the 10-metre high Martin Luther King in white stone. But one would have wished there to be fewer stereotypes involved, for the women to appear as individuals, and asked whether they were of the sharing kind or not etc. Women in this group portrait clearly remain a homogenous, stereotyped group, whose views (if any) one presumes to know: those of the "other".

The work's genre, oil painting, is in the $21^{\text {st }}$ century deeply problematic. One could point to Joseph Beuys' dictum that the problem already arises if someone goes out to buy canvas and easel: for the last half century (if not for an entire century, since abstraction first emerged) it has been difficult to be taken seriously as a figurative artist. Whether through Gerhard Richter's "blurring" of painted photos or Luc Tuymans" "bleaching", artists have developed strategies of gesturing to their knowledge of the fact that in art-historical discourse painting has "died" (and thus could only be attempted to be "reborn") - and, like Francis Bacon or Marlene Dumas, of finding ways to convey fluidity or movement in portraiture, hinting at the fact that we (certainly in the academic world) no longer think in categories of unchanging identities (Lelijk). The stylistic allegiance of this work lies in the 1960s or earlier, in any case before the emergence of conceptual art. In broad swathes of the population of many countries, figurative painting is the unthinking equivalent of "Art". In the Netherlands, this is not the case: in Vitaly Komar and Alex Melamid's famous art project The Most Wanted Painting, begun in 1995, where they searched for many nations' favourite artworks, the Netherlands was the only country, where abstraction won (Govan n.d.). It makes this progressive country the envy of those involved in the artworlds of all other places in the world. Of course, there are also in the Netherlands, and apparently even in a university's Faculty of Humanities, those who equate art with figurative painting. Here, most likely, a positive and value-bestowing nod to colleagues and students whom one knew to be involved with artistic practices was intended, aware that the majority of the sitters are among those (more of this later). 
One of the main problems with figurative painting as a genre is the difficulty to avoid a work looking like Socialist Realism, a style that, as Margolin aptly stated, was adopted by "authoritarian leaders around the world" (Margolin 2012, 200). ${ }^{5}$ The work's colour scheme helps the association with Cold War culture. Ilya and Emilya Kabakow have in very similar colours created installations that replicate the eerie feeling of Soviet-era institutions: hospitals, factory corridors and museums. Within Socialist (or generally anti-democratic) Realism, painting happy building-site workers and, indeed, academics, was mandatory: the less democratic a regime, it seemed during the Cold War, the more did it find it necessary (or even make compulsory) to present its subjects as smiling, i.e. as approving of the regime. It appears to be the current project's need to let all other elements of the sitters' personalities, or - especially critical - achievements, slip into the background and for the gratitude to be seen, at last, by the institution to take pride of place. The five UvA academics in any case are shown to be exceedingly happy about their visibility. In a colonial framework, the command to be "happy" (grateful for the "civilization" bestowed) e.g. took the shape of a verse that was a compulsory part of the Irish school day during British colonialism, where the pupils had to characterise themselves as "a happy English child" (Boylan 2005, 121). Unease about the facial expressions may be what the critic intuitively objected to when she considered the painting a "theekransje": in academic circles, a probing, critical attitude is most valued (de Vries 2019; Boomkens 2016).

From a feminist and art-theoretical point of view, visibility of women is a rather two-edged sword, as the following quote by Peggy Phelan elucidates:

I am not suggesting that continued invisibility is the 'proper' political agenda for the disenfranchised, but rather that the binary between the power of visibility and the impotence of invisibility is falsifying. There is real power in remaining unmarked; and there are serious limitations to visual representation as a political goal (Phelan 1093, $6)$.

Of course, loved ones still commission paintings of their kin, and institutions still wish to add to their galleries of portraits, "updating" them by making them more diverse in terms of gender, for example. That did not happen here. Individual portraits of these five women - ideally in their own preferred medium, featuring their own wishes concerning "insignia" of their 
research, in what clothing they would have preferred to represent themselves, and which artist, medium and style they would have chosen - would have been an entirely different story. For one, the meeting rooms would not still exude an exclusively male air and thus, as we know, subliminally or not, affect future Faculty decisions.

The problem with this Faculty choosing the private creative painting practice that usually does not attract art-historical scrutiny, in order to represent some of its most accomplished academics, is that this choice communicates at least an unfamiliarity with modern and contemporary art history, as well as, in particular, with artistic research. Aafke Hulk, on her retirement, stated in a parting FredVlog that one of the crowning achievements of her tenure as Dean of the Faculty was to have established collaboration with the Rietveld Academy in Amsterdam, i.e. to have paved the path that has led to the UvA leading (or at least involved) in the field of Artistic Research (ARIAS website). ASCA, the research school that Mieke Bal established, celebrated its twenty-fifth anniversary with a discussion on, among other topics, Artistic Research (ASCA website). The chair group of Modern and Contemporary Art History offers a Research Masters in this area, as well as PhD research; it produces publications about Artistic Research and funding for it. The relevant Research Schools emphatically support these efforts: ASCA and the Amsterdam School for Heritage, Memory and Material Culture (AHM). José van Dijk, as former Royal Academy of Science (KNAW) director has done much to integrate the Academy of the Arts into the Royal Academy research structure, thus also taking (visual) artists seriously as researchers. ${ }^{6}$

Not that there is a problem with academics privately favouring oil painting that has no conceptual ambitions or - on probing - iconographic, theoretical or interpretative coherence. When representing the Faculty's ambitions, however, it may have been more advantageous not to contradict so directly the conceptualization of the relationship between art and research espoused by the majority of the sitters, by Faculty policy with regard to artistic research, represented by ARIAS (ARIAS website), or the academic discipline(s) to which this project directly pertains within the Faculty. Faculty interests could have served as inspiration to ask some of these players how artistic research can help fix the - indeed serious - lacuna of those female professorial portraits identified, or at least enquire in advance how the planned work would be interpreted and where it might best be sited to convey the intended message. 
To summarize thus far: the painting contradicts its "feminist" purpose by being both commissioned and painted by men. I am not of the opinion that men cannot produce (or commission) feminist work. But the process of decision-making concerning this commission does not seem to have taken account of the individual accomplishments of the sitters, nor in-house (or local, national, or international) disciplinary expertise. Instead, it got caught in an incoherent choice of medium and iconography, as well as a style whose meanings and politics are counter to the stated intentions. The presentation of a diversification of faces in the decision-making spaces (the rooms adorned with male portraits) has also not happened, because the work is being displayed elsewhere.

The painting hangs in the administration building of the Faculty of Humanities at the UvA, a semi-public space (anyone can enter off the Kloveniersburgwal). It is in the foyer of the socalled VOC-room, in the floor below the meeting rooms with the male Professors' paintings. It is the commissioner and present Dean Fred Weermann's achievement that, in 2018, explanatory text panels were installed in front of the room in which the VOC had its administrative centre (UvA website: Bushuis). These panels mention for the first time that Dutch colonialism, achieved through the VOC, whose power centre the UvA now occupies, is problematic, i.e. through trading in enslaved human beings. It also reveals that the current appearance of the room is owed to a 1979 restoration: the room itself is lavishly painted, has a sturdy wooden chest, (presumably for maps, contracts and/or money), and features (reproductions of) paintings of the former Dutch East Indies. Where the VOC took its decisions is where the main Faculty meetings now take place.

Displaying the painting of the five female academics in front of the (most often locked) VOC room (perpendicular to its entrance) shows very valuable awareness of intersectionality: the emancipation of, equality for, and opportunities accorded to women and colonized peoples is related. It follows, for example, that becoming a Professor is difficult, but not as difficult for a white woman as for a woman of colour. As an outcome of the Diversity Report that ensued from protests against cuts in the Humanities in 2015/16, the Faculty has taken steps to embed the issue of diversity into its structure. These efforts are still in flux. As the current painting project shows, diversity is close to Weermann's heart. Particularly apt with regard to intersectionality is the fact that, in comparison with the Staalmeesters model, the group portrait of the 
women is missing one member (there are five instead of six sitters). This gap, in the context of the painting's placement, could be understood as echoing the University's wish to include (at least) one (emerita) professor of colour in this group - and it certainly signals its inability so far to diversify sufficiently. There is no similarly accomplished female professor included in the painting who is not white, or not Dutch, as the opportunities for academics from elsewhere, especially formerly colonized regions, were lacking for too long. It follows that they were lacking, of course, owing to institutional racism, cascading bias etc.

In art history, one would point to Linda Nochlin's famous essay "Why Were There No Great Women Artists?" (Nochlin 1971) and translate this as "Why Are There No Great Women Professors of Colour?"7 Might it not have been possible to find one? To appoint one and postpone the project until such a time as it had the capacity to be really inclusive? The criterion for who would be depicted is not a given, of course, but one constructed by the commissioner. The University has received funds from the Dutch government to help with the fast-tracking of improvements in the under-representation of women in higher rungs of the academic community: Aspasia funds. These have, indeed, helped excellent female colleagues to progress. I have not become aware of there being a focus on women of colour, or even non-Dutch candidates succeeding in any higher proportion. ${ }^{8}$ Such inherently systemic inequalities become even more pronounced when considering the context: the University of Amsterdam, a city where the majority of inhabitants were not born in the Netherlands.

In the academic context today it would (we hope) be ludicrous if there was a discussion on feminist matters in culture and for there to be only male panel members. In keeping with academic practice, where people from a privileged, normative group refuse to sit on panels etc. that lack diversity (i.e. either people of colour and/or women), the artist could have refused the painting commission. Not only can he not assume to speak for a group of women (as mentioned), his work - once carried out - also automatically contradicts its intended message of vowing improvement in terms of the job opportunities that women have received and will receive in academia. This is the implied central purpose of the painting commission. The same disproportionality and dearth of opportunities is unsurprisingly to be found in the artworld, e.g. for commissions. For many men, the word "academic" or "artist" is obviously still gendered male and male artists appear as the "best" for any job, including a "feminist" one. To 
signal change here would obviously have demanded a female artist - and to also let the work and its location reinforce rather than contradict each other: a woman artist of colour (Crenshaw 1989; Williams and Dempsey 2018).

The worthy juxtaposition of a "feminist" painting and the "decolonial" VOC explanations in terms of making an intersectional point, however, is relativized by further factors: the tradition of portraits in oil painting and the iconographical model chosen for the painting. Rembrandt's Staalmeesters from 1662 originates from a time when Amsterdam's economic fortunes were flourishing, owing to a very large extent to colonial enterprise, i.e. exploitation. It was a "golden" age only for some. Culture, particularly oil painting, and even more particularly the portraits of those individuals involved in overseas trade, such as evidently the Guild of Drapers, served to represent these players' status. It also helped to create it in terms of cultural capital: elevating the source of the money by investing in art. This, to put it very simply, is close to what the now discredited sponsorship of art institutions by cigarette or oil companies similarly signalled.

It is unfortunate that not more thought was expended on which artistic media and conveyors of status one could turn to when choosing a carrier for the present work's message. However humble the women (wished to) appear, the pattern of an artwork bestowing power and status is established, especially for the Netherlands, by Rembrandt and his contemporaries. So apparently overwhelming was the thought that, in order to convey the importance of five women, the portrait tradition that cemented patriarchal and imperialist power relations (national wealth and identity) also had to be suitable for them. And it is still, apparently, suitable to be in a location where the shared disadvantage of colonized peoples and women is painfully and with academic rigour being highlighted. That assumption is - one cannot, I'm afraid, call it by another name - blinkered, i.e. selectively blind: it excludes historical and social realities, as well as overlooks the lasting damage of precisely those unquestioned, clearly still operating, power structures. The five women arguably reached their level of academic accomplishment because they questioned the normalcy of such assumptions. It is a question worth asking how - in today's universities - accumulations of official portraits (with their strong associations with personality cult or "genius") are to be treated and how we may convey through art a view of academic work as less focussed on the person, but more on the achievement - and maybe 
even on the communal and serving function of academic work. ${ }^{9}$

If, in the UvA context, say, a female artist working in photography had made a photographic work of five Dutch, white, female Professors among a more diverse group of young students and academics, the well-intended message would have been clearer. One painting in one frame as a well-meant antidote to centuries-long statistical under-representation with its attendant personal frustration, aggression and violence, when male professors can each have their own frame: that may also have been a point of attention before the unveiling. In the artworld such slip-ups happen as well, of course. When the first woman was in 2005 allowed to curate the Venice Biennial, it was deemed (in Italy with yet other gender relations) that it could not be one person, like the men, but had to be two (María de Corral and Rosa Martínez). One frame containing five women is not a respectful, "feminist", approach to equality.

If the money had been spent on scholarships for five young women of, for example, Indonesian ancestry who are the first in their families to study, the message would have yet been clearer. And modern and contemporary art historians or art(istic) researchers could have thought of an event, or something visual, that the students could have put in little frames to sit alongside the male portraits in the meeting rooms. In contrast with that kind of idea, the portrait as it is might show excellent but humble women, but as valuable and as positive the intention is, the portrait project itself does not break with the colonial or chauvinist mindset it wished to critique. It lacks precisely that humility in inadvertently conforming to what Gloria Wekker has called "white innocence" (Wekker 2016). One of its most powerfully disturbing features is that Dutch white men seem to think themselves predestined to speak for people of colour, or, in this case, for female academics (Wekker 2018).

I owe insights into how this case parallels Dutch cultural policy to an essay by an MA student, Cathelijne Tiel. She summarizes the effects of the Dutch Code Cultural Diversity (CCD) launched by the sector in 2010 as follows:

the norm, the white prerogative, is taken as natural and is placed in opposition to the racialized other who becomes the embodiment of 'diversity'. As a result, the discourse of diversity revolves mostly around the 'diverse or ethnic other' who is deviant from the norm. Even though the norm is left unseen, it is confirmed by the very negation of what it is not. What is at stake here, is the politics of in/visibility: the regulation of 
visibility by power dynamics. The current diversity debate is about making the other visible, often from a dominant position, but without taking into account this position of power and privilege. [...] Diversity becomes that positive progressive ideal, a sign of a rich multicultural society which finds its representation in the institution of art. However, at the same time it displaces racism and injustice from the public view. According to [Sara] Ahmed [in A Phenomenology of Whiteness]: 'It is the very use of black bodies as signs of diversity that confirms such whiteness, premised on a conversation of having to being: if by having us the organization can 'be' diverse' (Tiel 2019, 7).

Thus, even if there had been a "black body" in this painting, the othering of those depicted would still have continued. As it is, the presence here (and not in the meeting rooms etc.) of women arguably subscribes to the same logic: that through this commission, i.e. by showing the "having" (of women) in the dominant institutional self-understanding, suggests a "being" (inclusive) - notably without changing power relations or creating enabling conditions. The painting, if not accompanied by concerted action outside of the symbolic world, effectively serves a retrograde purpose in providing an excuse not to act. ${ }^{10}$ In Ahmed's words: "Diversity here is not associated with challenging disadvantage, but becomes another way of 'doing advantage"” (Ahmed 2007, 238). ${ }^{11}$

At the beginning of this essay, I invited a comparison of the UvA portrait with the flaws of the Martin Luther King monument. That comparison ends here: I cannot fault the Martin Luther King Foundation that commissioned the memorial, nor Barack Obama or his followers for opting for and cherishing a 10-metre statue, however much one may wish that choice to have been different. Just because each of its elements contradicts the life and achievement of the man depicted, the work served the clear need to come from "below" and eventually "also have" something of a size and nature that society is accustomed to understanding as a signifier of power and importance: for black people to finally arrive among those honoured in monumental stone. The UvA case is the obverse in this regard: the commission and the painting were done from "above" and betrayed the wish to retain the customary formal and medium language, despite their contradictory and counterproductive baggage. What is visible is a wish to not need to unlearn first, or to ask others, or devolve such a process, i.e. to see one's own privilege 
and freely give from it - to reap different kinds of rewards, rewards that are bestowed in reputation, motivation and "verbinden" of staff, research excellence, and even university rankings - to an institution that is truly inclusive.

To return to the portrait: when looking at the painting alone, i.e. without direct reference to the Staalmeesters, there does not appear to be a gap that visually demands to be filled. One may hope that a young, black and/or foreign, female student may stand in front of this painting in its semi-public location and feel as though the mirror were to invite her to be part of this group. If she knows art history, though, she will be able to read the cues and know that a square mirror facing the viewer in the centre of a painting, as in Diego Velázquez' Las Meninas, is reserved for the reflection of power looking on: the commissioners of the work. She is likely to find in this work confirmation that the institution is not for her and see this painting as having a disciplining effect, that it takes part in a process of domination, in what Gayatri Chakravorty Spivak has called "epistemic violence" (Spivak 1988).

Students do their work at tables underneath the canvas, whose visibility is of course an important part of conveying its inclusive intentions. In a moment of boredom, aggression, or out of unfamiliarity with how one may treat a canvas, they may, however, deface or damage the painting. The portraits of men, both in the meeting rooms and in the places where $\mathrm{PhDs}$ are defended or their outcome debated (Agnietenkapel, Aula), are safely behind lock and key. Only the portrait of the female professors is in such a vulnerable position that its fate is uncertain. We know for a fact that there is gender-related violence (verbal, sexual and otherwise) in the university and LVNH's findings confirm the more vulnerable position of female students and staff alike in Dutch universities. The location of the painting replicates this vulnerability, left prone to such aggressive behaviours if they were to materialise against it. One of the legion of recent reports on how universities do not tackle racism and gender bias in their institutions includes the following quotation: "'There is no person of colour in a senior level position,' she said: 'I think this is why when I called out racism they tried to silence me, as there is really no one with the same lived experience as me"” (Batty 2019). For female academics from nonnormative backgrounds, the painting likely confirms, rather than betters, other negative experiences they are statistically likely to have had (and not to have reported).

When the UvA Law Faculty's failings in ensuring the safety of its female staff and students 
was revealed, not long after the unveiling of the painting, a group of staff which had formed during the 2015 protests, ReThink UvA, met with students from de Nieuwe Universiteit and the University of Colour to discuss the situation. It seemed apposite to meet in front of that aspirational portrait, and with blu tack stick the demands for the safety and equality of women on pieces of paper around the frame. The site where this deeply flawed work is mounted has become a site for discussion, a place for strategizing. This may yet lead to the equality, status and safety for women that the portrait appears to celebrate. At that moment in the future, the portrait will have become contemporary art: part of a social practice that is a shared one in the Faculty and that comes from "below". In the meantime, the well-meant commission and the painting itself - in every aspect of the project that calls for interpretation - so far is mainly a testament to the road that still remains to be travelled. The painting seems to shout that deceptively easily-read optics matter - instead of dealing with the substance and its enabling conditions - and that power thinks it does not need to listen: not to the sitters, not to expertise, nor to women and (other) marginalized people. The shortcomings thus far lie in a self-satisfied adherence to majority privilege. ${ }^{12}$ This is widespread in the Netherlands, where Government representatives often address the press in front of oil portraits of white men. But I would like to argue that it is neither in keeping with excellent academic thinking of the kind that is characteristic of worthy UvA academic work, nor with art.

If the painting may yet become part of a social practice, there is also an artistic research project in the making (for whoever wishes to take it on). On the day of the unveiling, I met with Walid Raad, who was installing his retrospective at the Stedelijk Museum. I explained where I was going, as he and Mieke Bal know each other from the time when Raad, as an artist, was pursuing $\mathrm{PhD}$ research and Bal worked in the US. Hearing of the project, Raad became very interested and suggested that "someone should film this. Is someone filming this?" (Raad 2019).

The case I presented is not isolated, nor removed from the bigger picture of (cultural) politics in the Netherlands, as Tiel already stated. The artist clearly studied (and is practicing) far removed from academic thinking and practices, so far removed that the potential need to refuse this commission did not occur to him. In most other (European) countries, art education and universities are considered to be at the same level. That this is not the case in the Netherlands has many damaging effects, not just in this case. At another level of policy, the President of 
the UvA's Executive Board rightly called the right-wing political party "Forum for Democracy's" "reporting point" for critical teachers and academics (those who teach climate science and, most likely, modern and contemporary art history) "respect-less" and "against all that the university stands for" (van der Hee 2019). The Party’s leader, Thierry Baudet, describes the following as the basis for his racist and neo-colonial vision: "the beauty of Dutch cities and paintings" (Baudet 2019). It should follow that studying (or in art uncritically using) these artefacts, such as Rembrandt's group portraits, should not be assumed to be a neutral pursuit today.

I would not have felt the need to write this essay if the painting commission's implications were just to call out some unthinking, traditional views. It is potentially more dangerous than that: when radical politicians hijack for their nationalist agenda artworks that were created well before the age of a thinking in nations (Anderson 1982), and well-meaning traditionalists play into their hands by finding no other marker of status than that same colonial tradition (while of course adhering also to the notion that one of the national markers of excellence is the inclusivity of Dutch society), it may be time to ask for that inclusive self-understanding to be filled with meaningful life. If it remains as blind and hollow as this painting commission shows it to be, the merging of forces (e.g. in culture and education) of conservatives and radical right-wing thinkers may be closer than we think. People educated in the neighbouring country to the East (like me) have learned to have painful associations in such cases. And Art History in the Warburgian tradition teaches one "seismographically" to read the signs of shifting cultural "tectonic plates", sometimes on the basis of a single artwork. The President of the UvA's Executive Board has thankfully already spoken clearly about where she wishes her University to stand. The visual culture of this institution should follow suit.

At the unveiling of the painting, it was remarkable how little was mentioned about the achievements of the five women portrayed, and how happy some of the male professors present were; they had themselves photographed in front of the frame that safely contains the women they do not quite understand and who will, whatever happens, keep smiling. Phelan's, Irigaray's, and Ahmed's words about the difficulties of visual representation as a goal come to mind. W.J.T. Mitchell adds: "When women speak out, when blacks obtain literacy, when the masses find an articulate voice, they break out of the regime that has constructed them as visual 
images" (Mitchell 2003, 53). This can arguably give some guidance as to a future direction one may wish to pursue in relation to art, research, and education, but away from ocular-centric ways to envisage inclusion.

In the wake of the painting's unveiling, there was a marked absence of reflected art criticism. That is understandable, as (and it has been investigated here) the work does not signal that it is an art project to be taken seriously, one that would warrant attention in the usual art-critical frames. But it also had something to do with the further education of the students who sat my exam and thought that this was a feminist project. I hope that, come second year, they will know to ask whose voice the artist's is, for whom it is speaking, and ideally a hundred more questions about form, knowledge, money, and power. Creating such awareness is an uphill struggle, however, as at the UvA there are (not surprisingly after what has been said) far more resources given to teaching facts about oil painting and Rembrandt than to teaching students how to think critically with and through culture. Currently, $4 \%$ of first-year teaching in the BA Art History is done by modern and contemporary colleagues - even though the students are proportionally far more interested in this latter art-historical practice, which thus, of course, also generates more resources for the Faculty. In other words, there is much need and opportunity for critical vigilance in Art History, but not the time or, for example, the resources to pay critics and make their profession sustainable. It is, as we have seen, not a healthy state of affairs, even for the necessary learning process within the Faculty itself.

A major advance in art history is [writes Victor Margolin] the recognition that formalism alone [does] not determine a work's meaning [- nor, I would add, do iconography or intention -] but that the totality of meaning depends on a relation between the work's appearance and the conditions of its production [...] and all the other factors that, in [Margolin's] case, contradict the spirit of Martin Luther King Jr.'s life and what he fought for (Margolin 2012, 408).

...And in ours the work of five remarkable colleagues. Art history, in encompassing iconography and connoisseurship, but going well beyond it too (as I hope this example has shown), has the wonderful ability to render even a supposedly one-dimensionally "feminist" painting commission as far from unambiguous: finding a formalist or iconographical "solution" to the (one, positivist) meaning of an artwork is a thing of the long distant past (and when looking to Warburg, as I have done, has never been the aim). Arguably, it is advantageous to include in any 
analysis of institutional visual (and other) practices the ability to look in detail and take all aspects of, for example, an artwork's commission, production and reception seriously. This, I hope, can create an awareness of clear epistemological solidarity with theorists and philosophers, who are used to approaching these matters in other ways. Together we may reach an insight that academics and artists (especially artistic researchers) are called to (and can uniquely) convey: valuing ambiguity is as good a route to sound research as it is to an inclusive society. ${ }^{13}$

One message from this case may be that the analysis of the Dean and commissioner was right all along: when there are just portraits of men in places of decision-making and when these places have as difficult a history as the VOC room and its surroundings, then the perspective can narrow all too conveniently, but dangerously, for the normative group in terms of becoming isolated. And he also rightly felt that art may break such an institutional status quo. Not only has Weermann invited a screening of Mieke Bal's most recent film project (UvA website: $\mathrm{Bal})$, but the entire Bushuis is now to become a research building with, among others, 4D and linguistic labs, and which will also include artistic research as an active player in re-envisaging the university's relationship with the building's history and with the city (UvA website: Humanities in Context).

When Hito Steyerl set about to define artistic research - or rather to go beyond a normative approach - her example was the building of the Linz Academy, Austria, with its own traces of a difficult past (Steyerl 2010). She credibly outlined the rich and varied ways in which particularly artistic research approaches such a challenging task clearly and academically: in ways that do not erase complexities. The subtitle of her important essay is "Artistic Research as Discipline and Conflict". To turn artistic research into a discipline immobilizes the struggle, and all academic disciplines are to be seen from a perspective of conflict and social struggle. An interdisciplinary research building will thus invite critical perspectives (undoubtedly including unpleasant ones). The current essay sought to provide one perspective from art research on certain "politically correct happenings" (Hoogland 2019) ${ }^{14}$ as steps on the way to where the Faculty should and can be. It is my hope that the "Staalmeesteressen" will find a more suitable place, for example one among the portraits of men in the room off the Aula, ${ }^{15}$ where $\mathrm{PhD}$ committees meet; that the painting will become a cautionary tale, and that the 
"VOC zaal" and attendant rooms find a future as interdisciplinary research labs and curatorial / artistic research studios, where we hope to work with art institutions like de Appel. Here, we can become invested in the search for better processes, thoughtful artistic iconographies, and methods beyond optics and representation to indicate what we value. ${ }^{16}$ This will be a vibrant and critical space for academic work and artistic practice that radiates into a more inclusive community, inside the university and out.

\section{Notes}

1] See Folia, 19 June, 2020: https://www.folia.nl/actueel/138876/fred-weerman-en-geert-ten-dam-ditis-ongehoord-beschamend

2] See the Dutch Network of Women Professors (LNVH) statistics. See also: Naezer, van den Brink, Benschop 2019. The mentioned poll took place in 2015, in the context of what an open letter on the ReThink UvA website describes: http://rethinkuva.org/blog/2015/03/02/letter-humanities/

3] "Faculteit Der Geesteswetenschappen Onthult Schilderij Van Vijf Vrouwelijke Hoogleraren," Universiteit van Amsterdam website, 10 May, 2019, https://www.uva.nl/shared-content/faculteiten/nl/faculteit-der-geesteswetenschappen/nieuws/2019/05/schilderij-vijf-vrouwelijkehoogleraren.html - See this site (and the press coverage in the following references) for illustrations of this work.

4] These conversations are conducted e.g. in the e-mail distribution list of ReThink UvA, see: ReThink UvA website.

5] I am not presuming that "Socialist Realism" is one style, to be identified by formal(ist) criteria. It is to be understood as all realist or figurative artwork that serves a regime, in the case of the Central and Eastern European countries during the Cold War, "real existing Socialism". I am thus jumping ahead a little in already presuming that the work serves the governing, in this case patriarchal structures more than that it questions or changes them, as it would be in keeping with the overt message. It is - to a certain point - possible to convey any and all (political) messages in an artwork of any style. Thus, formal analysis in itself also holds no prescribed political meaning.

6] Bram Kempers (2019) mentioned that there were no images visible in the papers featured in this portrait of colleagues who were very much involved with the visual domain. This was his main point of criticism of this work, which he chose as an example of art patronage.

7] In 1986, Chila Kumari Burman wrote an essay / manifesto with the title: "There Have Always Been Great Black Women Artists". I thank Katy Deepwell for the information.

8] The debate has yet to begin as to how universities wish to understand and promote inclusivity when the Aspasia funds are running out. The scheme is seen as successful and over time no longer necessary. See the Dutch Research Counci's (NWO)'s “Aspasia," website.

9] In a context that may have certain correspondences, the post-Apartheid institution of the South African Constitutional Court, judge Albie Sachs and his colleagues opted against official, painted portraits of judges and for small black-and-white photographs documenting the membership of the Court - alongside the establishment of a sizable art collection with a focus on diversity and human rights. 
See Stacey Vorster's forthcoming PhD thesis, UvA.

10] This danger of the co-option of Social Practice has within the UvA in 2006 been aptly analysed (Boomgaard 2006).

11] Tiel continues: "[T]he person in power, who does acknowledge this power imbalance and who wants to change it, sees oneself [sic] somewhere other than implicated in the critique. [...] they put[.] themselves on the sideline, as if not part of the societal problem." (Tiel 2019, 8).

12] The Artistic Director of the Amsterdam Museum, Margriet Schavemaker, has reminded her audience in her Inaugural Lecture at the UvA that Amsterdam knows no majorities, just minorities (and remarked that there was one particularly unassimilated one: white, Dutch males). (Schavemaker 2019). 13] See: Gielen 2020. He quotes Else Frenkel-Brunswik. 1949. "Intolerance of Ambiguity as an Emotional and Perceptual Variable". In Journal of Personality, no. 1, 108-143. - For art's unique ability to convey contradictions without flattening them, see e.g. Mitchell 2003.

14] In Dutch: "Het werd kortom een politiek correcte happening."

15] A particularly apt place would be the side-room of the Aula, where this painting could replace the portrait of Dymph van den Boom, the former Rector, who was found to have copied and not acknowledged passages in many speeches at openings of academic years etc. The portrait shows her in the Maagdenhuis, surrounded by students and staff in the 2015 protests. These protests were organised against the managerialization and financialization of the university. To present herself in the centre of this group, as if it had gathered to praise her policies, is a falsification of history. If she had formulated the portrait's message in words, it would clearly stand as such, i.e. as unworthy of an academic institution. Images should, this essay argues, be taken seriously, too.

16] As a recent example that achieves what the commissioners of the Martin Luther King Jr. memorial failed to do, Patricia Kaersenhout's exhibition Guess Who's Coming to Dinner Too? at de Appel in Amsterdam should be mentioned. It shows, among other things, the intertwined iconographies of feminist and coloured peoples' struggle for equality in that it models itself on Judy Chicago's Dinner Party from 1974-79. See: Kaersenhout 2019. It is also actively invested in scholarship and redrafting a communal sense of who "owns" art and the cultural and academic fields. See: Ziherl 2019.

\section{References}

Ahmed Sara. 2007. "The Language of Diversity." Ethnic and Racial Studies. 30 (2): 235-256.

Anderson, Benedict. 1982. Imagined Communities. London: Verso.

Amsterdam Research Institute of the Arts and Sciences (ARIAS) website: https://arias.amsterdam/

Amsterdam School of Cultural Analysis. University of Amsterdam. https://asca.uva.nl/

Bal, Mieke. 2019. "Groepsportret Is Allesbehalve 'Kiekje Van Een Theekransje."” DeVolkstrant, 3 June, 2019 https://www.volkskrant.nl/columns-opinie/groepsportret-is-allesbehalve-kiekje-vaneen-theekransje $\sim \mathrm{b} 7 \mathrm{~d} 655 \mathrm{c} 7 /$

Batty, David. "Universities failing to address thousands of racist incidents." The Guardian, October 23. 2019. https://www.theguardian.com/world/2019/oct/23/universities-failing-to-address-thousands-of-racist-incidents

Baudet, Thierry. Speech following the European elections. May 2019. https://www.youtube.com/watch? $\mathrm{v}=\mathrm{ABtS0Hd12 \textrm {s }}$

Boomgaard, Jeroen. 2006. "Radical Autonomy: Art in the Era of Process Management." Open 
(In)tolerance 10, 30-38. http://www.skor.nl/_files/Files/OPEN10_P30-39(1).pdf

Boomkens, René. 2016. "Smile or Die! On the Future of Cultural Studies." Zeitschrift für Ästhetik und allgemeine Kunstwissenschaft 61 (1): 39-56. https://doi.org/10.28937/1000106272

Boylan, Thomas and, Tadhg Foley. 2005. Political Economy and Colonial Ireland: The Propagation and Ideological Functions of Economic Discourse in the Nineteenth Century. London: Routledge.

Burman, Chila Kumari. 1986. "There Have Always Been Great Black Women Artists." In Feminist Art Manifestos: An Anthology, edited by Katy Deepwell, , 45-48. London: KT Press. 2014. https://s3.amazonaws.com/arena-attachments/1015704/003bf3be0f1d2bbc8fe9a630c9896349.pdf

Cixous, Hélène. 1972. The Exile of James Joyce. Translated by A.J. Sally. New York. London: David Lewis. John Calder.

Crenshaw, Kimberlé. 1989. "Demarginalizing the Intersection of Race and Sex: A Black Feminist Critique of Antidiscrimination Doctrine. Feminist Theory and Antiracist Politics." University of Chicago Legal Forum 1: 139-167.

Dutch Network of Women Professors (LNVH), Monitor 2019. https://www.lnvh.nl/a-3209/womenprofessors-monitor-2019.

Dutch Research Council (NWO). “Aspasia” website. https://www.nwo.nl/en/funding/our-funding-instruments/nwo/aspasia/aspasia.html

Gielen, Pascal. 2020. "Laten we proberen onze fundamentele ambiguiteit te aanvaarden: Over de kwestie 'identiteitspolitiek'." De Witte Raaf 204 (March/April). https://www.dewitteraaf.be/artikel/detail/nl/4777

Govan, Michael. "Director's Introduction to The Most Wanted Paintings on the Web." http://awp.diaart.org/km/intro.html

van der Hee, Sterre. 2019. "Ten Dam spreekt zich vel uit tegen meldpunt Forum voor Democratie." Folia, 28 March, 2019. https://www.folia.nl/actueel/128169/ten-dam-spreekt-zich-fel-uit-tegenmeldpunt-forum-voor-democratie

Hoogland, Walter. 2019. "De Opening van het Academisch Jaar had weinig met wetenschap te maken." Folia, 5 September, 2019 https:/www.folia.nl/opinie/131584/de-opening-van-het-academischjaar-had-weinig-met-wetenschap-te-maken

Kaersenhout, Patricia. 2019. "Artist's Statement." de Appel Amsterdam. http://deappel.nl/en/files/artists-statement-by-patricia-kaersenhout.

Kempers, Bram. 2019. "Valedictory lecture as Professor of Sociology of Art at the UvA." Amsterdam 22 November, unpublished.

Lelijk, Timea Andrea, Representation of Irrepresentability: The Painted Portrait in the $20^{\text {th }}$ Century in the Works of Edvard Munch, Francis Bacon and Marlene Dumas, forthcoming PhD thesis University of Amsterdam.

Logtenberg, Hugo, and Clara van de Wiel. 2019. "Bij hoogleraar B. moisten de vrouwen hakken dragen.” NRC Handelsblad, 14 May, 2019. https://www.nrc.nl/nieuws/2019/05/14/bij-hoogleraarb-moesten-de-vrouwen-hakken-dragen-a3960238

Margolin, Victor. 2012. “The Martin Luther King Jr Memorial: A Flawed Concept.” Journal of Visual Culture 11 (3): 400-408.

Mitchell, W.J.T. 2003. "Word and Image”. In Critical Terms for Art History, edited by Robert S. Nelson and Richard Shiff, , 51-61. Chicago/London: Chicago University Press. 
Nochlin, Linda. 1971. "Why Were There No Great Women Artists?." ARTnews. http://www.writing.upenn.edu/library/Nochlin-Linda_Why-Have-There-Been-No-Great-Women-Artists.pdf

Naezer, Marijke, and Marieke van den Brink. Yvonne Benschop. 2019. Harassment in Dutch Academia: Exploring Manifestations. Facilitating Factors. Effects and Solutions. Dutch Network of Women Professors. https://www.Invh.nl/a-3078/harassment-in-dutch-academia.-exploringmanifestations-facilitating-factors-effects-and-solutions.

Phelan, Peggy. 1993. Unmarked: The Politics of Performance. London: Routledge.

Raad, Walid. 2019. Conversation with the author. Amsterdam. 9 May.

ReThink UvA website. http://rethinkuva.org/

Robinson, Hilary. 2006. Reading Art. Reading Irigaray: The Politics of Art by Women. London. New York: I.B. Tauris.

Schavemaker, Margriet. 2019. Inaugural Lecture as Special Professor (on behalf of the Amsterdam Museum) at the UvA. Amsterdam 26 September, unpublished.

Spivak, Gayatri Chakravorty. 1988. "Can the Subaltern Speak?”. In Marxism and the Interpretation of Culture, edited by Cary Nelson and Lawrence Grossberg, 66-111. London: Macmillan.

Steyerl, Hito. 2010. "Aesthetics of Resistance? Artistic Research as Discipline and Conflict." Eipcp 2010 (January). https://eipcp.net/transversal/0311/steyerl/en.html

Tiel, Cathelijne. 2019. "White Noise: Politics of In/Visibility in the Diversity Debate." unpublished student essay at MA level. UvA. October.

University of Amsterdam (UvA). 2019. "Bushuis/Oost-Indisch Huis.". https://www.uva.nl/locaties/binnenstad/bushuis.html

University of Amsterdam (UvA). 2019. "The future of the humanities". https://www.uva.nl/en/sharedcontent/studentensites/fgw/fgw-gedeelde-content/en/events/events/2019/10/the-future-of-thehumanities.html

University of Amsterdam (UvA). 2019. "Video installation Mieke Bal in the Bushuis." 25 September 2019. https://www.uva.nl/en/shared-content/faculteiten/en/faculteit-der-geesteswetenschappen/events/events/2019/09/video-installation-mieke-bal-in-the-bushuis.html

de Vries, Sophia. 2019. “UvA schilder deze theekrans snel over.” de Volkskrant. 28 May, 2019.

Vorster, Stacey. Forthcoming PhD thesis on the art collection of the Constitutional Court, SA. Amsterdam: UvA.

Williams, Joan, and Rachel Dempsey. 2018. What Works for Women at Work: Four Patterns Working Women Need to Know. New York: New York University Press.

Wekker, Gloria. 2016. White Innocence: Paradoxes of Colonialism and Race. Durham/London: Duke University Press.

Wekker, Gloria. 2018. "Nawoord: 'Maar hoe zit het met de kapitein'." In Witte onschuld: Paradoxen van kolonialisme en ras. Amsterdam: AUP, 269-276.

Ziherl, Vivian. 2019. "Dining with the dead and the living". de Appel Amsterdam. http://deappel.nl/en/files/dining-with-the-dead-and-the-living-by-vivian-ziherl

\section{Biography}

Christa-Maria Lerm Hayes is Professor of Modern and Contemporary Art History, University of Amsterdam and academic director of the Amsterdam School for Heritage, Memory and Material Culture. Until 2014 she was Professor of Iconology in Belfast, where she led a Research Graduate School. 
She studied in Heidelberg, London and Cologne, where she gained her $\mathrm{PhD}$ (researched as James Joyce Foundation Scholar, Zurich). She held an Irish Research Council Post-Doctoral Fellowship, UCD. Her research focuses on word and image studies, visual legacies of (Irish) writers, performance, the historiography of art and curation. Rooted in Joseph Beuys studies, she is interested in sculpture, performance, social practices, post-War art histories and art research. Her books include: Brian O'Doherty/Patrick Ireland: Word, Image and Institutional Critique (ed., Valiz 2017); Post-War Germany and 'Objective Chance': W.G. Sebald, Joseph Beuys and Tacita Dean (Steidl 2011); James Joyce als Inspirationsquelle für Joseph Beuys (Olms 2001); and Joyce in Art (Lilliput 2004). She has curated at: Royal Hibernian Academy and Goethe Institut, Dublin; Tolstoy Estate, Russia; MoA, Seoul National University, Korea; Golden Thread Gallery, Belfast; LCGA, Limerick; CCI, Paris; Maagdenhuis, University of Amsterdam; M HKA, Antwerp, and the VanAbbemuseum, Eindhoven. 